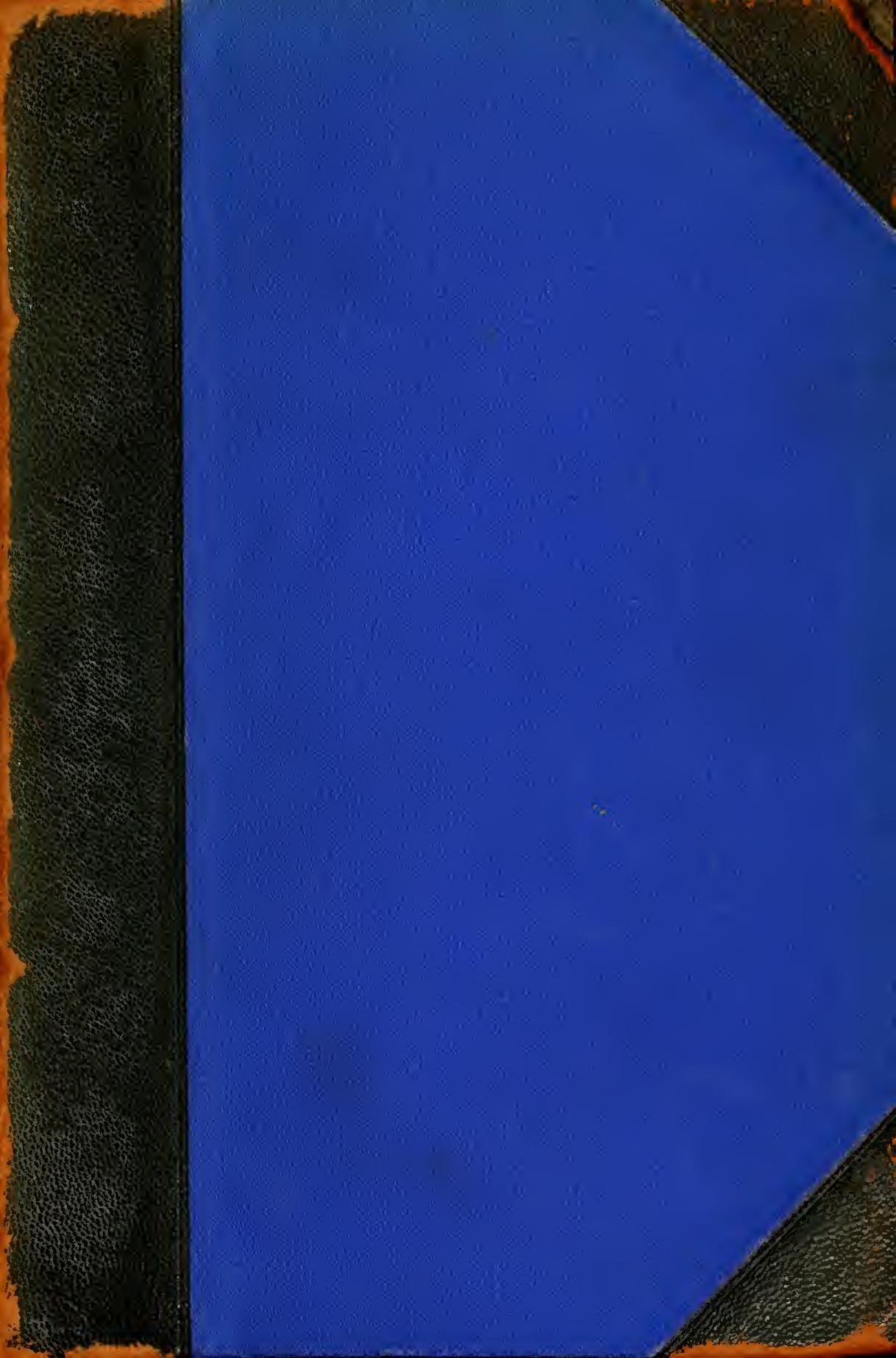




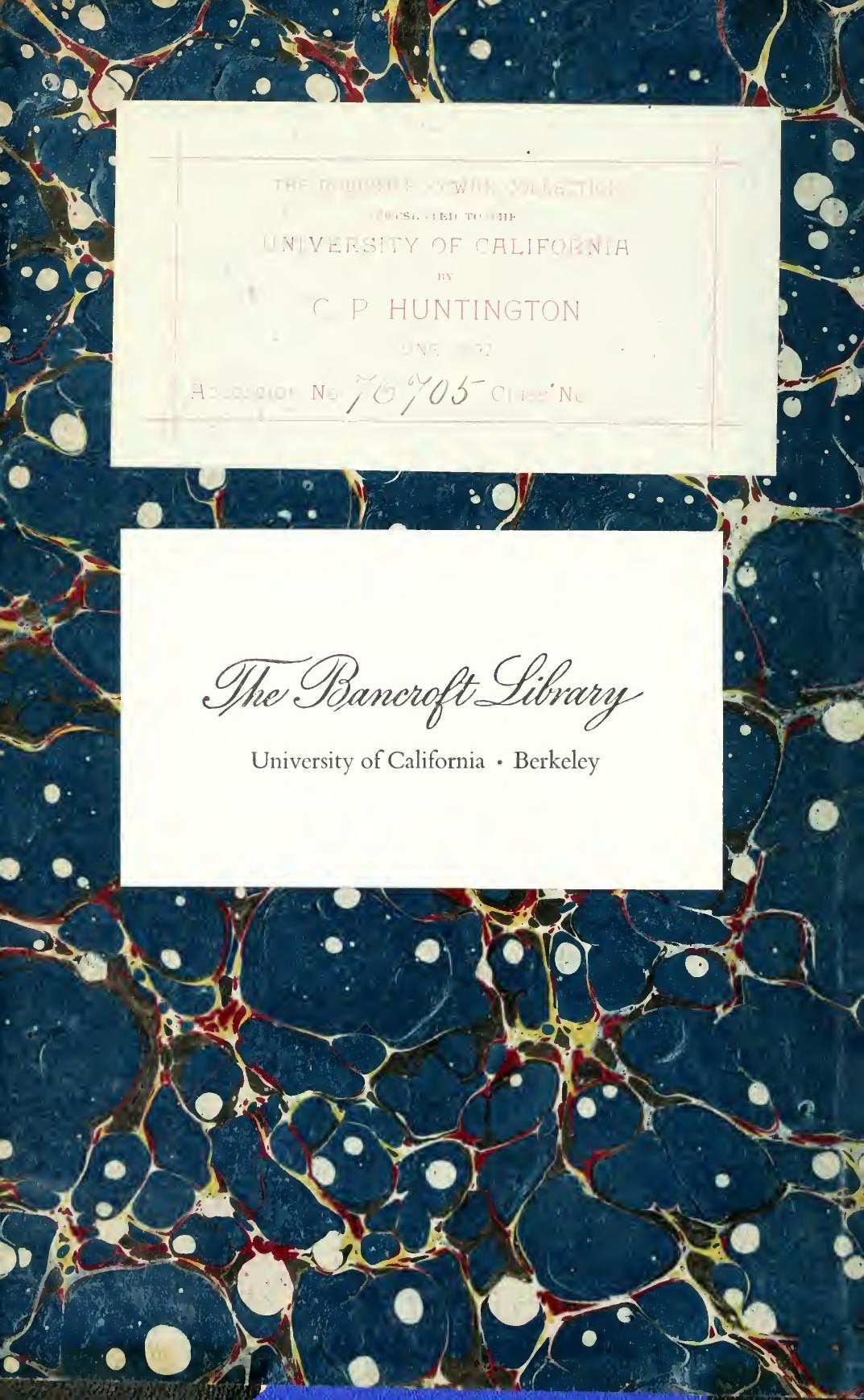




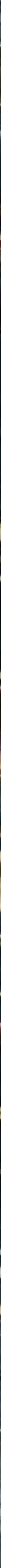


Digitized by the Internet Archive in 2008 with funding from Microsoft Corporation 


\title{
BOTTS' AIR-SHIP.
}

\section{The Problem of Aerial Navigation,}

\author{
BY \\ BARNET N. BOTTS.
}

PASO ROBLES, - - CALIFORNIA. 
The inventor is sending out this paper for the purnose of securing tinancial aid to build a practical working air-sbip. Several suggestions are also malle, and ideas ailvanced, in regard $t$ ) different forms of airships. Having applied for a ITnited States patent, and ueglecting to explain in the specitication the laws upon which the invention is based, when the case canıs up for examination the Examiner louked upon its succeseful operation as being somewhat doubtiul, without the use of a gas bield to suspend it in the anr, and the Patent Office held it to be inoperatice, calling for a model capable of ascension and propulsion. A mactuine will have to be furnished before any firther uction will be taken by the office. This will be a very expensive machine to build and the inventor is not prepared hinancially to carry it out. He bastaken this course, callitig for help, by sendiug ont this paper to Scientific and Aeronautical Societies, thus placing it before those who will comprebend the fundamental principles upon which the invention is based. The inventor txpecis no assistance except by giving undoubted proof that his machin is practical.

The following explanations are given in the form of a discussion between i and $B$, in order that the points may he brought out more clearly. Believing: the following explanations are sufficient to convince the most skeptical, in regard to the successful operation of the macbuse, the inventor is prepared to correspond with those who may be interested in tbe invention.

A-Mr. B, I, understand you bave invented an air-ship, and $I$ an bere to criticise on your invention. I aru an engineer by profession, and during my life, have made Natural Philosephy a study. I wish now to deal orly with fundamental principles. You will understand. Mr. B, that in urder to determine the prossibiitits of $4 \mathrm{n}$ invention, we nust look beneath the form, to the law; and there the facts will be disclos. d, which will tell tise-tory of its pos-ibililies. Now I wab you to give a clear and exnct explanation of the laws upon which your inventisu is based. I will he your critic while you give your explanation.

B-Mr. A, in regard $\omega$ the general feature of uy air-suip, it consists of a horizunral, ciglr-straped cylinter, with n central, uprignt, hollow mast. An air.compressur and unmor ure phed within the cylinser, the cylincler forming the cur. The inlet ripes io the air compressor open bit at the top sille of the car The Ontlet pipes extend from the compressor up into the hoilow mant. When they bave reached a point above the top sicte of the car, they extend horizontally in opposite directions and at right angles to the leugth of the car.
Their ends then extend vertically downward and form flairing nozzles. The action of the compressor draws the air in through the inlet pipes and throws it out turough the outlet pipes. 'Thus the air entering the ialet pipes vertically downward, will by the so called suction lift the ship vertically 11 pward, and the air flowing vertically downward from the outlet pipes or nozzles, past the sides of the car, in the form of jets, will by reaction from the outer atmosphere. push tue ship verticaily upward. We thus have the lifting power of the suction nozzles and the onl Alowing jets of air. The mouths of the air jot ntzzles are placed atove the center of gravily of the ship, tu prevent capizung, as the main lift cones on them, and they are resting on the pointed ends of cones of compressed air. The nutaths of the nozzles are nade flairing to prevent the lissing nonse of conrpressed air passing then, which would otherwise occur. A large horizontal plane is fixed on the mast mentioned above, and in case the nachinery should cease to act, and the ship start to fall, this horizontal plane is forced sidexise against the air which slides it up a short distance along the mast which it surrounds. This action of the puane opens a valve mad adnits commressed air from a chamber within the car, to the jet nozzles. The jets of air flowing from these nozzles, form aerial warachutes; and this stored up emergency power will mantain them till the ship can safely descend to the earth. To maintain the shipin an upright position duriug flight, plumb bobs are fixed nyon the car, capable of swinging back and firth and sidexise. In case the ship tills from an upright position, the plumb bubs maintaining a vertical posi. tion, open yorts and throw a jet of air from a nozzie extending in the direction to which the ship is tilted. The renction of the jet ot air rights the sbip.

A-Mr. B, have you not yet learned that wh enormons anount of energy 18 consumed in producing an air jet whose reaction is compuratively not bing?

B-Yes, Mr. A, I have learned that this is or is not the case.

A-Mr. B, you understand we have been trying for a long time, to get up an air-ship cajuble of ascension withont the use of a gas fieid. You also understand that wo steam engune or other motor, bas ever been capable of lifting itself in the air. The difficulty Mr. B, has been this: we have never been abie to get a motor sufficiently light, for the amount of energy it produced. It simply consists in securing a lizhter motor with a greater power. When we advance far enough in this direction we will nnvigate the air. 
13-Mr. A, I am prepared to tell you I have a different course to pursue, from lout which you mention. I have discov-red a way to donble, quadruple and mulliply the lifling capacity of an uir-ship, nlmost withont linit. Mind you, this can he accomplished withont increasing the weight or nower of the motor, or weight of any part of the air-ship. You understand the different motors as we have them now in their prosent condition, are capable of lifting themselves into the air and many times double their weight. They alregdy yield sufficient mechunical power to do all this. But in all air-ships so far, the main portion of the power has been wasted, brcause it has never been properly applied. It has not been the sans and forms of the atr-ship which were ar falt, but their proportroris and incline surfaces and the like. It seems thrt these inventors or builiters of air-ships have not umlerstood the luws upm which their inventions were based; and the rusult is, they have not had those laws to guide them to success. It has been like trying to solve a problem in mathematics without a rule,

A-But Mr. B, I want an explanaion about how you are going to increase the lifting capacity of your air ship witbout increasing the power of the sustaining motor.

B-Mr. A, it is accomplished by air jets of large volune, under low pressure and velocity.

A-Mr. B, do you mean to say that a jet ot air of large volume under low pressure sud velicity, lifts a gredter weight than oue of smaller volune with nigh pressure and velocity, with equal amounts of energy consumed per secund in eacli case?

B-Yes Mr. A, that is just what I mean to say; let us force a large volume of air under low pressure and velochy, through passages of large dimensions, and we are on the road to success. Furvillustration, we will take two air-ships +xactiy alike in form unu weight, but in one the nozzles and aerial passages throughout contan greater diameters than the other. To be exact we will say they cuntain just right times the area of the other. A given puwer with the enlarsed area, will lift just double the wight to that in the uther case, nor is il necessary to increase strength or weight of the parts upon which the strain of the combressed air rext $*$, for the resson that as the dimelusions of the parts are enlargen, the air uressure $p \in r=q u a r e$ inch is reduced proportionally.

A-I understund your theory Mr. B, nuw I ask you to prove all this. It is very easy to say this is so and so, but it is another thing to prove it.

B-yon are aware of the fact Mr. A, that if we double the yelocity of a body moving through the air, we will quadruple its resistance. Suppose Mr. A, we have two parachutes; one has an area of one bundred square feet, and the other an area of four hundred square feet. We place on these parachutes loads which make them descend at equal velocities. We place on the larger one a load of one hundred pounds, ani in order to muke them descend at eijual rates, we place on the smaller one a load of twenty-tive pounds, for the reason that it contains only one fourth the area of the larger one. Now if we place a load of one hundred pounds on the smaller one, this load will cause it to descend at such a rate that it will be constantly meeting with the same resistance from the air as that of the larger one at its slower velocity. And this rate will he double that of the larger one, for the reason that we have quadrupled its resistance against the air, by dubbling its velcity. Thus you observe, it we qnadruple the area of a parachute, it is compelled to de-cend at ouly one half that of its former rale, in order to meet with the :ane resistance. In this case of the falling parachutes, the parachutes themselves are supposed to contain equal weights.

Suplose Mr. A, we have a combination consisting of a steam engine and boller; and on the outer end of the piston rod we have tixed a bruad plane having an area of one hundred square feet. Sinpose we so arange this combination that the piston roct by the action of the stenus, moves the plane constantly $v \vdash r$ tically downwarl sidewise against the air. We will call this comlination an ilinstrative air-sbip. The plane being noved vertically downward, reacts against the air aud cend- to lift the ship and hold it in the air. Suppose this plane has to be noved downward against the air, at the rule of one bundred feet per second, in order to gain sufflcient reaction to sustain a weight of one bundred pounds. We now remove this plane and replace it with one having an area of four hundred square feet. Now according to the lawsillustrated in the case of the parachutes, the engine has to move this larger plane at only fity feet per second rgainst the air, in order to gain sufficient reaction to sustain a weight of one hundred pounds. What is this we have? A plane with an area of one hundred square feet, noying against the air at the rate of one hundred feet per second and sustaining a weight of one liundred pounds. And in the second case a plane having an area of four hundred square feet, moving at the rate of lifty feet per secoud and sustaining a weight of one hundred pounds. Now in the first case, the engine has to move a load of one hundred pounds, at the rate 
of one hundred feet per second, in order t) sustain a one hundred pound weight. And in the second case, it has to move a load of one bundred pounds, at the rate of only fifiy feet per second, to accomplish this. Mr. A, you are well aware of the fact, that it requires double the nower to move a load at the rate of one hundred feet per second, to that which is required to move it at the rate of fifty feet per second. You now observe the advantage of the larger plane. It only required one-half the power to sustain the one huudred pound load, by using the larger plane, to that which was required to sustain tho same load with the smaller plane. Sothen it comes to this: We can lift the one bundr d pound load with one-haif the power, if we quadrupe the area of the plane. Now if we choose we can double this quadrupled area of the liane and lift two hundred pounds mateas of one, by using the full power of the motor. Mr. A, you are probably aware of the fret, that in the case of the well known water wheels, where the pawer is applied by throwing jets of water againat paddles tixed upon their peripherirs. that they require gearing accoriting to the velocity of the jet by which thev are actuated. A large jet under low prosure anif velucity. rotates the wheel with great force, but at a slow rate of motion; and a small jet under high pressure and velocity, rotates its wheet at a high velocity, thongh it has but little force, till we introduce gearing to decrease the motion and increase the purchase. Keep in memory the fact, that in the case of both the large and small jets, they are suproved to transmit equal amounts of energy per second, from their nozzles to their wheels. It is clear Mr. A, that the constant strai:s between the nozzie and paddles on the wheel, in the case of the larger jet with low pres. sure and velocity, is greater than that in the other case, although they are transmitting ezual amomts of energy per second, from their nozzles to their wheels.

Mr. A, I read an arconnt in a Scientuic paper, which illustrated this law: The statement was made that a spiders weth forming a belt an's placed on pulleys currespondingly dellicate, would by traveliug at the velocity of light, transmit about two huodired and fify borse power. You are aware of the fact, Mr. A, that in that case an enormous amount of energy would be transuitted from point to point per sfcond, but the strain upon the veluicle which conveget this pliergy would be excedingly small. Now Mr. A, the larger plane in the case of the ilnstralive nir-shin, and the larger jet of water in the ense of the water wheels, represent the lurger jet of air in the case of the air-ship. They illustrate the fact, that as we decrease their velocity, we increase their pressure or reaction; And in the case of the spiders web traveling at the velocity of light, the fact is sbown what a great anount of energy can be transmitted from point to point per second in the case of the air jets with but little pressure or reaction as in that of the spiders web, Now we may consider it a natural law, that for transmitting a given amount (f energy, in a given time from point to point, as we increase the velocity of the vehicle conveying this energy, the constant strain or pressure on this vebicle is decreased, no matter what form or nature this vehicle is. It nay be planes of air-ships moying directly or indirectly against the air. It may be a belt fixed on pulleys, a revolving shintr. or a reciprocating piston rod, a jet of water or a jet of air. $\mathrm{Th}$ se are all simply cases of transmission of eneryy from prist to point. To make this case nure clear, in regard to trasumitting enersy from point to point, we will for illustration snppose a belt to carry one bundred pomnds at the rate of $t+n$ feet per stcount. It will then transmit from point to point on thousind foot pounds of energy jer sec nd. We now suppose the bett carries a loal of fifty pounds; you understand then it will bave to carry this linal at the rate of twenty feet per second, in order tr transmit the one thousand foot pronnds per second. You observ in this case, that we doubled the velocity of the vehicle and transmitted the one thonsmil tout pounds per second, though the strain upen the vehicle was only one-half that in former case. This then makes it clear, that as we increase the speediof the vebicle carrying a given amount of energy per second, we lessen the strain upon it, and yet convey the same amount per second as before. Now in the caseof the air jers, they are similar to bent sarunge whacel betw en bearings. The springs being in a state of ten-ion and pressing equaliy againat each of their bearings. The months of the nozzles form on" of them bearmgs and the outer atmosphere the other. And the weake-t points in the air-jet springs (sball I call them) are immediately at the moutbs of the nozzles, where the velucity of the jets are greatest.

A-But .Mr. B, I suppose we shall have to give up the idea that a small propeller moving at a high velocity, will bring ahout as great a restion as a large one moving at a slow velocity, with an equal power in each case to actuate them.

B-Yes Mr. A, that idea will have to be given up in all forms of propellers. A plane moving broad-sided directly or indirectly against the air, is practically the same; and this law we have been 
discussing applies to all.

A-Then Mr. B, You mean to say this law applies to all air-ships, such as those using horizontal screws, aeroplanes etc.?

$\mathrm{B}-\mathrm{Yes} \mathrm{Mr}$. A, it applies to all, independent of their form. You understand Mr. A, that in the case of propellers moving against this yielding medium, -the atmosphere, our object is to secure a fouthold; and if this foothold yields in the least, under the pressure of the propeller, it meaus just that much dead loss in the eneryy of the motor. The larger then the surfuce of the propeller, moving against this yieldiug medium, the better is the foothold, and the less the loss of power. In order that there be no loss of power, the area of the propeller must be brought to such great dimensions, giving such a great foothold on the air, that it will not gield at all from the pressure of the propeller. But these dsmensions call never be reached, either in practice or theory. The practical dimensious which may be reached, can only be determined by experiment. So we muy conclude without a doubt, that in all air-ships of the coming future, at best, we will always have a heavy and unavoidable loss of energy from this source.

$A-M r . B$, in regard to a revolving horizontal screw, I suppose you mean to crowd the air vertically downward, thus gaining the reaction to lift the ship.

B-Yes Mr. A, that is the idea.

A-Mr, B, suppose I had an air-ship on this plan, what change would I have tu make, to double its lifting capacity, without increasing the power of the sustaining motor?

B-You would have to nultiply the area of the blades of the screw to eight fold.

A-Mr. B, I would like to ask you the same question in regard to the air-ship witb aeroplanes.

B-Mr. A, suppose in the cases I am about to explain, that the air-ships during their flights are to remain at a constant elevation, and in all cases to move at the same rate, and exuctly horizontally. Now Mr. A, you may double the lifting capacity of the ship by nultiplying the area of the aeroplane to eight fold, and tixing it at such an incline from a horizontal position, that it will crowd the air downward from its, under surface at one-half that of the former rate. In this case the area of the blades of the screw which propells the ship, do not have to be moditied. And there is another way Mr. A, in which you can double the lifting capacity of your ship without increasing the power of the sustaining notor. It is accomplished by doubling the area of the aeroplane and letting it remain at its former incline, And then undtiplying the areas of the blades of the screw to eight fold.

A-Mr. B, in regard to modifying the area and incline of the aeroplane, and areas of the blades of the screw, in order to double the lifting capacity of the ship without increasing the power of the sustaining motor, I want you to explain this: Why are these prrticular changes necessary to bring abıut this result?

B-Mr. A, They are in harmony with the law pointed out in the case of the illustrative air-ship. where the fact was shown we might by multiplying the area of a plaue to eight fold, and allowing its surface to moye against the air,eitber directly or indirectly at one-hali its former rate, double the lifting capacity of the air-syip. Now in regard to the ship with the arroplase; You nultiplied the area of the aeropiane to eight fold, and bixed it at such an incline that itwould crowd the air down at only cne-half the former rate. The aeroplune uow descends in the yieldiug air at ouly onr-balf its former rate. And at the same tine it is gliding upward, I might say at owe-half the former rate, thus remaining at a constant elevation. The aeroplane now, does not have to be pusbed up so steep an incline as before. With its load it has only to be glided upward in the air balf so high in a giyen time, and decends only half so far in that time. For this reason it will sustain double the load with the former power, and in regard to the stcond case of modifying the aeroplane, you doubie its area and lift it at its former incline. Thiy doubled area calls tor double the borizontal pressure, to move the ship at its former rate carrying donble the load, because of the incline of the aeroplane not having been changed, and $w$ as compelled to glide upward in the air at as steep an angle as before any moditications were made and at the former rate. Or we can illustrate the case equally clare by saying, the aeroplane crowded the air downwari. and this doubled horizontal pressure was then secured by multiplying the area of the blades of the screw to elght fold. Now the explanation of the moditied areas etc., of the screw blades of the airship using horizontal screws, explains the philosophy of those on the ships using aeroplanes. The revolving horizontal screws crowd the air downward practically the same as the plane in the case of the illustrative air-ship, as do the aeroplanes, for the inclined blades of the screw are only aeroplanes moving in a circular patb; and in the case of the illustrative air-ship, it was shown that when the area of the plane was multiplied to eight fold. we could lift double the weight without increasing the power. for the same reason we can do so in this case. Accrding to fundamental principles we are not confined to any particular 
incline in case of the blades of the horizonial screw. If we modify their incline, and rяи-e tl:eir mane to lie more nearly parallol to the plane of rotation of the screw, then lies can not crowd the air so far awa duritg each revolution of the screw. The velocity of the screw would then hale to be increased in order to nove the nir away at the same rale at which it was nuved before we modnfied the incline of ti.e blades. And since we have this mudificalion, it will simply result in a higher velucity of the -crew. In the encl the serew woutd move the air awav at the same vate as before we moditiet the incline of its blades. Let ne say Mr. A, that experiment wight proye a marticular incline of the blates of the screw in lue of the grealest imporlance, even if general primeiples do indicale the reverse. Now I destre to suggext. Mr. A, a plan for an air-s.hip whuse power is supplietl by stored compresseit air. It contains a long horizontal cylinder filled with compressed air at a very high pressure. The cylinder forms the bosy of the air-ship. Enlarged nozzles are to be phaced along the sides of this cylinder, une row on each side, the rows extending along the full length of the cylinder with their mouths extending downward. The nozzles in each row ar placed one immediately in the rear of the other. Huring the flight of the shin, the mazles in each row will all move through the sane yath and present little surface for resistance against the air. Their moutlis which are the points of suspension for the ship, are placed above the center of its gravity to prevent capsizing. The compressed air will fow through small pines into the enlarged nozzles and there expand and produce a lower pressure hefore pasing out frum them into the ofwn air. Thus we have by weans of the enlarged nozzles large volumes of air Howing from them under low pressure and velocily. which produces a far greater reaction or lifting power, than laat the compressed air flown directly into the outer atmospbere b+fore descending to a lower pressure and larger volume. We also have a large number of eularged nozzles, thus sesuring great nozzle urea and consequent economy of power. In regard to the appliances to maintain the ship in ru upriglt position during its tlight, and to prevent it from falling in case of accident, the arrangementy mentioned in the air-shin above, using air jels, are equally adapted to this cace. lisut you will understand $\mathbf{M r}$. A, that the ship could not travel as long journeys as those carry ing an engme and feul. It would have to land occassionally for a renewed supply of compressed air. You understand it is possible to carry only a fraction of the energy in the form of compressent air, to that which may be carried in the form of oil, coal etc.
A-- Vr. B, I want to suggest rolacing a suall engine on a ship of this kind, and when o i a long jurney land oecassionally atd supply fat lur the rngine, and charge the sbip with a new supply of compressed air while resting on ine earils. Now Mr. $B$, would there not he a great less of energy by the comprased air descending (i) a low pressure before passing out from the entarged nuzies?

li-les, but th: material from whish the energy is extractio is not carried on the ship, so it nukes no chitference as ial as the air-ship is concerned.

A-ilr. B, in case the cylunder is of large dimensions, but thin and light, it would hold a large quantity of air at a low pressure: but if its dimensons are sumbler it would have to be very this:k and heasy in proporion to its dimensions, to hold ilie sama funntity of air, because of the himber pressure whsels is brought abont. Now it is ciesirable to have the dimmonions of the eytinter small as pomilile in order that it nay be less buiky. But lle smatler alinder must lowd an eglual amount of air lo that of the Jariner me, indmpendent of its pressure. II e must have the large guantity of air independent of the dimensions of thecylinter, or pressure of the air within it.

A.-. Mr 13, I want to ask you this question: Would there be aly difference in the weighrs of the large and small cylinders, capable of holding equal quantities of compressed air at the different pres-nres?

B-Suppose Mr. A, we have a cylinder one foot long and one foot in diameter, and we have another one one foot long and six inches in diameter. Fach cylinder is matie of one-eightir mch steel. We will compress within the larger cylinder two cubic: leet of air from its normal yressure to olie alluosphere. We will compress within the smaller cylinder one cubic foot of nir The pressure in the larker s:ylimbl we suppose to be tifteen (in)unds per square inch, and in the -maller one thrty poutuds per square inch. The sualler eviluder lias a strain double that of the larger ome, but it can stind double the pressure, becanse it contains only one-half lite dianeter of the larger whe. The smaller cyinder contuins one-half the quanlity of air to that of the larger whe, jis wemht is also one-half that of the larger cylinder, and we suppose the two cyinders contain all the jressure they can bear. Now if we make the smaller cylinder of one-fourth inch steet in place of one-eighth, as before, we double its weight and strength. And being thiss strengthened we can compress within it twice the yuantity of air it contuined before. It will then con- 
tain the same woight as the larger cylinder and the same quantity of ulr. You then ubserve that their weights are the same in order to have sufflcient strenght to stand the pressure brought upon them, by containing equal quantities of air.

A-But Mr. B, if the compressed air Hows from the smaller cylinder, under its bigh prissure, into the enlarged nozzles, and there descend to a low pres:ure before passing out from them, there is a much greater amount of energy wasted than in the case of the large cylinder; hecause the pressure of the air mist descend Irum thirty pounds per squar inch in the case of the smaller cylinder, before doing useful work, and in the case of the larger cylinder it would only have to descend from fifteen pounds. You understand that in the case of the sualler cylinter, the compressed air contailss much more energy than that of the larger one, although the quantity of air contained in each cylinder is the same. Now Mr. B, we must necessarily have this high pressure in order to reduce the bulk of the cylinder. But 1 cannot fancy this enormous waste of energy. Can you suggest a way to provent this loss?

B-Mr. A, I suggest placing an air compressor on the ship, and alluw the stored compressed air frum its reservoir, to actuate this compressor while in the act of descending to a low pressure, and allow the exhaust from the compressor, which would contain sufticient pressure to supply the enlarged nozzles. The coupreysor then in return can compress nore air into the reservoir from which it received its energy, thus there is no loss of energy from that source. The extra weight added in the shape of machinery, is small in comparison to the power saved. Now $\mathrm{Mr}$. A, with all our different mir-ships, (those useing uir jets, aeroplanes, horizontal screws etc.,) We have made these changes and doubled their lifting capacities, wichont increasing the fower of the sustaining motor. The fact is then clear, that we can in a simllar way, increase their lifting capacities without linit, so far as this law is concerned The practicsl liuit cau unly be determined by experiment. In closing our discussion in regard to increasing the lifting capacities of the arr-ship, I will say the point we have been discus. sing is based on that all-important natural law, that to get the greatest reaction with a given power, we must bave the greatest area moving agaiust the resisting $m t^{\prime-}$ dium at the lowest velocity.

A-Now Mr. B, while we have all the arvantages of your plans, we must not vier-look the fact that it is desirable still to have the lightest possible motor with the greatest power, to operate our air-sbips. Can you suggest the plan of an engine which would be lighter than those we now have? You understand by increasing the dimensions of the parts in the air-ships as you bave suggested, that they are necessarilo somewhat bulky, which is not desirable, as there is a sreater surface to move against the air during their aight. And securing a greater power to a given weight of motor. means either to decrease the dimensions of the air-ship, or carry a greater load.

B-Yes Mr. A, there is plan by which this can he accomplished. It consists in working the steam at the lowest possible pressure. We suppose we bave a boiler furnishing steam at a high pressure; This high pressure calls for strong and heavy parts upon which it exerts its pres. sure. Suptose this boiler furnishes steam at a pressure of one-tenth that of the former. The reduction in pressure will permit us to reduce the strength and weight of the parts upon which the pressure comes, to onctenth that of the former. Yet this boiler generates an uany fout pounds of energy in given time as before, for the reason that this depends on the heating surface. The heating surface being as great as it was before, it then comes to this: We haye reduced the weight of the boiler to onetenth that of its origiual and yet it generates as much energy in a given time as before. But since we have reduced the steam pressure, we will bave to in. crease the dimensions of the steam chest to permit the low pressure to do mechan. ical work as fast as it is generated. You understand we nust have a greater pig. ton area. The area must be increased in proportion that the steam pressure has been reduced.

A-Now Mr. B, how abont diminisbing the weight of the water in the boiler?

B-Mr. A, i i case the water is cuntained in the spacis anong the thues of the boiler, the flues then should lie more closely to. gether, thus giving less water space. It would then require less water to till the boiler and coyer all the heating surface. The small auount of water then in the boiler would be converted into steam and pass out nore quickly into the condenser. to be returued by the injector. The result would be, that the smaller amount of water is used oper more frequently in a given time. It would probably be advisable to let the flues contain the water and allow the beat to pass through the spaces among then, for the reason that their diameters being small, they will stand the pressure witb less thickness and weight than in the case where a cylinder of larger diameter surrounding the flues, is required to stand the strain. This cylinder will require great strength and 
Neight bacause of its large diameter. $\Lambda$ idd for this reason, wlow no parts with large cimensions on which the stean jressure comes. In this latter case oniy a light hull is required to surround the flues, to conline the heat to its path. And it would require a greater iiterual strin to burst lhese tubes thun exterual pressure to collanise then. Now in this case, to secure the greatest heating slirface with the smallest water spact, the flues contuining the water should have as smatil a diancter as possibie, brcause if we lessen their diameters one-half, we will lossen the amount of waler thry contain to one-fourlh that of the forditr smount, and only lessen their healing surface one-liali. They may be matte much lighter with suflicient strengeh 10 stand the strain, because of their smaller dianueters.

A-Mr. B, while all these air-ships we have been discussing, may be hatisfactory for slow velocities, we cannot sutisfy our selyes without higher velocities. We should travel several hundred miles per hour, to carry our nails, if not paszengers. Are thers not fair prospects that we will soon alvance to tilis point?

$\mathrm{L}-\mathrm{Mr}, \Delta$, Yut have probabiy ubserved the flight of diliereut birds-we take the crane and the duck for illustration. Jun will ohserve the crane is pussessed of wiugs, or sustaining mechansm, with very large surfaces, in comparison to its weight, to move against the air. buc the reverse is the case with th: duck. Now the condition of th: erane wilh the large surface of its sustajning apluaratus, weans the greatest conomy of the energy stored within its bolly, becausc of the great areas of its wing nuving slowly against the air, being an exact representation of the enlarged areas of the sustaining surfaces of air-ships. Th. duck possesses on the contrary a lery heavy body in comparison to the area of $i t s$ wings, and you will observe during its Hight that its wings mone against the air at a lery rapid rate, in orler to sustain the rom. faratively great weight of its body. This nieans a great wast of its stored energy, and is a representerion of the sustaining surfuces of air-ships with small areas. Now Mr. A, it is not difficult to ubserve the difference in the Hight of these two birils. The Hight of the crane being excetingly slow and ankward, and the revarse being the case with the duck. Now while the duck turing its llight, loses far nore energy per second, to each pound weight of its boly than the crane, it has the conditions present to enable it to reach a far greater velocity; and these conditions could not be present without this heavy loss of energy.

1-Nr. B, what are these conditions that enable the duck to reach its rerid ascension aud flight?

B-Mr. A, you will observe the duck to be more compact than the crane; this is a conditıon suitable to rapid flight. but most important of all is the fact, that $\mathrm{jt}$ possesses the possibility of withdrawing from its suurce a far greater amount of energy in a given time, to euch pound weight of its body thau that of the crane. And in regard to the mechanism of the duck, which this energy must actuate to bring about the rapid ascension and borizontal flight, it is Indoubtedly a fact that the rapid flight is brought about by sucli a motion of the wings that they force the air more nearly directly backward, and at a more rapilf rate than that of the crane. And the smald sustuining surfaces or wings of the luck moving downward against the sir at a rapid rate, have a tendency when they have released the weight of the duck froiil its place of rest, to cause it to ascent wib a bound similar to that of a sky rocket, anl for a similar reason; while the crane with its cnlarged sustain. ing surfaces moving downward against the uir at a slow yeloity, is incapable of bringing about such a result.

A-But Mr. 13. what has all this about the duck and the crane to lo with arr-ships?

b-lt is my object to compare the build and proportions of alr-sbips to the build aul proportions of the duck and crane. You will ob:erve'the comparatively bulky, awkward aurl slow motioned ajr-ship with Jurge sustaining surfaces representung great econony in power, to be a repre. sentation of, and is built on the plan of the crane. But Mr. A, if we hope to reach any great velocities with our air-ship we must have the conditions of the duck. We must have the conditions present from which we can withdraw an enormous amount of energy in a short period of time. You understand we require a very large nnmber of foot pounds of energy per second to each pound weight of the ship, in order to handie it quickly. The slipis must, like the duck or skyrocket. be capable of rising from the earth with a bound. It must not consume an hour in rising a thousand feet high, but must yuickly rise to an altitude from which it takes jts horizontal flight, for the objest of this ship is to travel the greatest possible distance in a given time. And its rapid ascension is required for the reason th.t it must land frequently tu renew its store of energy. When wo stcure our energy and bring about the conditions in order that it may be used rapidly as desired, we will; like the duck, be able to ascend and travel borizontally with great velocity. But remember, the greatel portion of the energy, as in the 
in bringing about these conditions for rapid Hight. You understand that the sustaining surfuces of the ship, like that f the duck, will be small and suitable w rapid Hight.

A-Mr. B, I want to know sonething ubout how we are goung to bring about the cunditions of the duck in our air. shrp? Will the possibilities of mechanics und sources of energy permit thist to be accomplished?

I3-Mr. A, while we baye not quite reachel the possibilities of mechanics necessury for this condition, it seems as though it wonld not require much mven. tion to bring it about. And I will say thrt gas and petroleum engines nspear to be most suitable. There aplears 110 reason why they can nut be reduced til an excedngly small weight-to as low as two or three pounds per borse Dower I will vemture to say. And in regard to their sources of ellergy, they ful-hil that ali-important condition, in supplying the energy fant as required. We do not require all this heavy machinery, boilers, water condensors and so on, to be carried on the ship, as in case of the steam engine, to bring about that result. When we have thus reducedt the weights of the engines, we have tuat difficulty practically removed. In regard to the weight of the fuel, we lieed fear no difficulty, when it is considered that one pound of petroleum contains tifteen million foot pounds of enerpy; and there is no reason why we cannot secure two-tbirds of this for useful mechanicat work, when we make a little nore progress. All we require is to bring to perfection the gas and petroleum engines, and we can soon have an air-sbip, capable of traveling at a great velocity in the face of the beariest tornado that ever blew.

A-Mr. B, from what source will you secure your gas in case you use a gas engine?

B-It will be stored at a very high pressure in a reseryour on hosed the ship. If yon care to make the calculations it will not be difficult to deteruine the number of foot pounds of energy which can be thus stored, to each pound weigtut of the reservoir.

A-Mr. B, In order then that our ship sball reach this great velocity, and in view of the fact of its heavy loss of power even if we haye on board a large supply of energy, it will sooner or later becume exhaunted.

B--stations shall he arranged at suitabie points along the air-sbip line where the sbip lands and secures new supplies of "hergy. And the distance upart at which these stations should be placed will,depend on how far a supply of energy will curry the ship. While the ship consumes its supply of energy it will travel a great distance during that time. And here let me remark, that the above mentioned air-sbip with the stored compressed air and enlarged nozzles is suitable to operate on this plan.

A-Mr. B, What is your idea in regard to transforming the energy of petroleum directly into electricity? Of course you are aware, if it can be accomplished, of the advantages which would result, to aerial navigation.

B-While such a discovery would be of priceless value, it seens to sue that it will never be made. Yet there is such a great unkuown just before us-so much to discover and so little that has been dikcovered that we know not what is in store for us. Mr. A, you are aware that by lecomposing zuc with an acid that its stored energy, its chemical affinity. is released and eomes forth in the form of electricity. But suppose you try decomposing iron or steel with this acid. and its energy romes out in the form of hent, with $n$, electricity about it. I believe the redson zin: gives forth electricity, is becallee of its extruordinary cremical consitution, whic's no other malerial known to the writer possesses; and it seemy that it is not likely that petroleum possesses this condition in the absence of that in thousands of other materials which do not possess it. To come right to the noint $\mathrm{Mr}$. $\mathrm{A}$, it is undoubtedly a fact, that the mode of the atomical motion brought abuut by the decomposition of zinc, is alltugether different from that of other naterials, and this mode of motion hapreus to be the same as that brought about in the coily of a dynamo by the magnets passing them. Heat is evidently a simple reciproctring atumical motion. While in the case of electricty, we have the best of evidence by its manifestations, if not positice proof, that it consists in a rotary recuprocating motion, of polarized atums on an uxis. It seens to me that a familiar substunce like patroleum, if it con. tains the possibility of giving forth electricity, would have given some manifes tution of it through accident or experiment. Now Mr. A, while I hope my vlews are wrong in regard to this, 1 fear they are correct. And if they are, there will be other methods developed wbich will contain as small a weight per horse power in machinery as is possible in this case.

And in bringing our discussion to a close. I will venture to say that the dawning of the twentietb century will find us operating air-sbip lines across continents exploring the unknown regions of the earth by their aid, and possibly soaring across the seas.

BARNET N. BotTs,

Paso Robles,

January 1st., 1894.] California. 







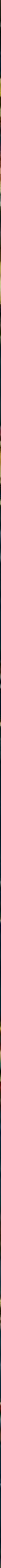


